СД-9.

\title{
ИССЛЕДОВАНИЕ ЭЛЕМЕНТНОГО СОСТАВА НЕФТИ \\ МЕТОДАМИ АЭС-ИСП И МС-ИСП
}

Гребнева-Балюк О.Н., Кубракова И.В., Тютюнник О.А.,

Лапшин С.Ю., Пряжников Д.В.

ФГБУН Институт геохимии и аналитической химии им. В.И. Вернадского РАН,

Москва, Россия

grebneva@geokhi.ru

DOI: 10.26902/ASFE-11_102

Элементный состав нефти, в первую очередь содержание никеля и ванадия, характеризует возраст и происхождение нефти, исходные регионы и пути миграции углеводородов; эти данные используются при поиске месторождений. Содержание других элементов позволяет учесть важные прикладные аспекты, связанные с использованием нефти как энергетического ресурса: экологические риски при ее добыче и переработке, эффективность использования в качестве топлива, предопределяет технологию переработки, а также характер добавок, улучшающих свойства нефтепродуктов при транспортировке. Таким образом, желательно, чтобы информация о составе углеводородных систем была максимально полной.

На примере нефти различного состава (включая сверхвязкую) показана возможность детального элементного анализа природных углеводородных систем методами АЭС-ИСП и МС-ИСП после микроволновой (МВ) пробоподготовки.

Установлена возможность и выбраны условия микроволнового разложения образцов легкой и тяжелой нефти массой 0,5-1,0 г. Исследованы влияния остаточной кислотности и остаточного углерода на формирование аналитических сигналов в АЭС-ИСП и МС-ИСП (высокое разрешение). Показано, что АЭС-ИСП и МС-ИСП-определение элементов в нефти после МВ разложения с использованием автоклавов iPrep (CEM Corp.) можно проводить после калибровки спектрометров с помощью стандартных водных растворов, без привлечения дорогостоящих, а порой и недоступных, стандартных органических растворов.

Показана возможность АЭС-ИСП определения 19 элементов на уровне 100n - 0,0n мкг/г и 36 элементов МС-ИСП определения (с высоким разрешением) на уровне 100n - 0,0n нг/г в выбранных условиях МВ подготовки и измерения. Оценены метрологические характеристики (предел определения и стандартное отклонение). Получены данные о микроэлементном составе нефти ряда месторождений России.

\section{Список литературы}

Гребнева-Балюк О.Н., Кубракова И.В., Тютюнник О.А., Лапшин С.Ю., Пряжников Д.В. Исследование элементного состава природных углеводородных систем на примере анализа нефти методами АЭС-ИСП и МСИСП // ЖАХ. 2020.

Работа выполнена при поддержке РФФИ (грант 18-29-06044 мк). 